\title{
Initiative and Voting in Common Foreign and Security Policy: The New Lisbon Rules in Historical Perspective
}

\author{
Ramses A. Wessel \\ Professor of the Law of the European Union and other International Organizations, Centre for European Studies, \\ University of Twente, The Netherlands; Centre for the Law of EU External Relations (CLEER), The Hague
}

Draft; to be published in: Herm.-J. Blanke and Stelio Mangiameli (Eds.), The European Union after Lisbon: Constitutional Basis, Economic Order and External Action, Heidelberg/New York: Springer, 2010

\section{Introduction}

The entry into force of the Lisbon Treaty on 1 December 2009 is generally believed not to have had a large impact on the Union's Common Foreign and Security Policy. In fact, most commentators would argue that the 'second pillar' remained in place. ${ }^{1}$ The place of CFSP as the only policy area in a separate treaty (the TEU), even distinct from all other rules on external relations (in the TFEU) indeed supports this view. In addition, the treaty itself makes quite clear that "The common foreign and security policy is subject to specific rules and procedures" (Art. 24.1 TEU). Hence, at first sight, CFSP maintained the 'intergovernmental' nature that it, allegedly, had when in was established in $1992 .^{2}$

However, over the past years research revealed that these days CFSP is clearly different from the policy that was created twenty years ago. ${ }^{3}$ The legal order of the European Union proved to have its own dynamics, which resulted in an increasing number of similarities between CFSP and the policies of the European Community. ${ }^{4}$ Step by step the subsequent treaty modifications introduced sometimes rather technical innovations, which in turn led to a new legal and political situation. In addition and apart from formal treaty changes, the CFSP legal order was affected by the case law of the European Court of Justice, which further defined its relation to the external relations of the Community as well as the

\footnotetext{
1 Cf. Cremona 2006, as well as Cremona 2003.

2 At the time of the formation of the European Union it was quite common to view the non-Community parts of the Union as "a legal framework based on international law". See Denza 2002, p. 5.

3 Obviously, the development of Europe's foreign and security policy goes back to the years of the European Political Cooperation before the CFSP, which meant that CFSP did not have to start from scratch. See for instance Smith 2004.

4 See more extensively Wessel 2007 and Wessel 2009. Compare for a political science perspective also Stetter 2007.
} 
effect of its instruments. ${ }^{5}$ This development was even labelled 'progressive supranationalism' by one (close) observer. ${ }^{6}$

The purpose of the present paper is to take a closer look at two elements in the CFSP decision-making procedure: the right of initiative and the voting rules. These two elements are generally believed to define the distinct nature of CFSP when compared to other Union policies. After all, both the exclusive right of initiative of the Commission and the turn to (ever more) qualified majority voting (QMV) belong to the 'Community method' which over fifty years characterised European cooperation. ${ }^{7}$ By comparing the current (post-Lisbon) treaty provisions on the right of initiative and the voting rules with the ones in previous texts, we hope to be able to point to a progressive development in this area. Based on earlier research on the development of the CFSP legal order, ${ }^{8}$ our hypothesis is that the new Lisbon rules on the right of initiative and the voting rules shows a move towards a less intergovernmental CFSP, or perhaps even a 'progressive supranationalism'. 9

Section 2 will first of all deal with the right of initiative to submit initiatives and proposals under the CFSP rules. This will be followed by a related issue: the right to convene an extraordinary Council meeting (section 3). Section 4 will deal with the basic rule of unanimity and the introduction of the so-called constructive abstention. The core of this issue is to be found in the exceptions to the unanimity rule; do we see a shift towards more QMV in CFSP? (section 5). Section 6, finally, will be used to draw some conclusions on the development of the CFSP legal regime regulating the right of initiative and the voting rules.

\section{The Right to Submit Initiatives or Proposals under CFSP}

\subsection{From Maastricht to Nice}

The importance of the right of initiative is to be found in the fact that it defines the source of CFSP decisions. Ever since the Maastricht Treaty the right of initiative was above all used by the Presidency to initiate new CFSP decisions. Although the Presidency was not mentioned in the original treaty, it could base its actions on the fact that it was a Member State. The original Art. J.8 TEU-Maastricht listed the same provision in its paragraph 3 in the following wordings:

\footnotetext{
5 More extensively: Hillion/Wessel 2009. See further van Ooik 2008.

${ }^{6}$ See (Director of the Legal Service of the Council) Gosalbo Bono 2006, p. 349.

7 This is not to deny that other elements may be of equal importance, in particular the role of the European Court of Justice and the involvement of the European Parliament in the decision-making process.

${ }^{8}$ See references in supra, note 4.

${ }^{9}$ It goes beyond the scope of this paper to further define 'intergovernmentalism' and 'supranationalism'. The bottom line, however, is that we hope to reveal a move from a 'Member States driven' policy to a policy that is defined and implemented at EU level.
} 
Any Member State or the Commission may refer to the Council any question relating to the common foreign and security policy and may submit proposals to the Council.

The absence of an exclusive right of initiative for the Commission was one of the characteristics that distinguished CFSP from the Community policies. Although from the outset the Commission had a shared right of initiative under CFSP it has barely used it. The reason is that the Commission held that CFSP belonged to the Council. To quote former Commissioner Chris Patten: "Some of my staff [...] would have preferred me to have a grab for foreign policy, trying to bring as much of it as possible into the orbit of the Commission. This always seemed to me to be wrong in principle and likely to be counterproductive in practice. Foreign policy should not in my view [...] be treated on a par with the single market. It is inherently different". ${ }^{10}$

The original text was maintained by the 1997 Amsterdam Treaty (Art. 22 TEUAmsterdam) as well as by the 2001 Nice Treaty (Art. 22 TEU-Nice).

\subsection{From the Constitutional Treaty to the Treaty of Lisbon}

The first modifications could be found in the 2005 Treaty establishing a Constitution for Europe, which - as is well-known - never entered into force, due to negative referenda outcomes in France and the Netherlands. Art. III-299.1 TCE provided the following text:

Any Member State, the Union Minister for Foreign Affairs, or that Minister with the Commission's support, may refer any question relating to the common foreign and security policy to the Council and may submit to it initiatives or proposals as appropriate.

First of all, this provision allows for initiatives or proposals to be submitted by "the Union Minister for Foreign Affairs", either individually or "with the Commission's support". The Constitutional Treaty introduced the "Union Minister for Foreign Affairs" as the successor of the "High Representative for Common Foreign and Security Policy", introduced by the Amsterdam Treaty. It thus introduced a new, more supranational, element into the CFSP by allowing initiatives in this area to be taken by an 'agent' of the Union, rather than just by

\footnotetext{
${ }^{10}$ See Spence 2006, p. 360.
} 
Member States. By 2005 the High Representative (the Spanish politician and diplomat Javier Solana) had developed into a key player in CFSP, while making sure that he had the support of the Member States for his actions. Providing him with a formal role in the decision-making process could certainly be seen as an important breakthrough in the character of the Union's foreign and security policy. It is interesting to note that by using the term 'Union Minister' the Constitutional Treaty went beyond the recommendations of the Convention on the Future of Europe. In its Final Report, Working Group VII on External Action had proposed the term "European External Representative". As the report notes with obvious premonition: "Other titles have also been put forward in the course of discussion, notably 'EU Minister of Foreign Affairs' and 'EU Foreign Secretary'. The prevailing view was that the title of 'European External Representative' had the advantage of not corresponding to a title used at national level."11

The other 'supranational' element in this phase of the decision-making process could be found in the competence of the Commission. On the other hand, as we have seen, from the outset the Commission decided not to make use of its formal right of initiative. This is not to say that the Commission was not involved in CFSP. The Commission was, and still is, represented at all levels in the CFSP structures. Within the negotiating process in the Council, the Commission is a full negotiating partner as in any working party or Committee (including the Political and Security Committee). The President of the Commission attends European Council and other ad hoc meetings. The Commission is in fact the 'twenty-eighth' Member State at the table. Practice thus showed an involvement of the Commission, both in the formulation and the implementation of CFSP Decisions, not in the least because Community measures were in some cases essential for an effective implementation of CFSP policy decisions.

The Constitutional Treaty deleted the individual competence of the Commission to submit CFSP proposals and replaced it by a possibility to submit initiatives together with the new Union Minister for Foreign Affairs. It thus introduced three sources for CFSP proposals and initiatives: the Member States, the Union Minister, and the Union Minister together with the Commission. We will come back to some implications of this division below.

The version in the TEU is similar to the one included in the Constitutional Treaty. Article 30.1 TEU now provides:

\footnotetext{
${ }^{11}$ Final report of Working Group VII on External Action, CONV 459/02 (16.12.2002), footnote 1.
} 
Any Member State, the High Representative of the Union for Foreign Affairs and Security Policy, or the High Representative with the Commission' support, may refer any question relating to the common foreign and security policy to the Council and may submit to it initiatives or proposals as appropriate.

The only difference is the replacement of the term 'Union Minister for Foreign Affairs' with 'High Representative of the Union for Foreign Affairs and Security Policy'. This replacement was caused by the changes discussed during the Lisbon IGC with the more general purpose of removing 'state like' terms. At first sight, the scope of the High Representative's competences seems broader because of the extension to 'security policy', but in fact the reason was to only marginally change the already existing name of the function, introduced by the TEUAmsterdam ("High Representative for the Common Foreign and Security Policy"). Although not explicitly mentioned in Art. 30 TEU, proposals of the High Representative may cover the Common Security and Defence Policy. Article 18.2 TEU explicitly provides:

The High Representative shall conduct the Union's common foreign and security policy. He shall contribute by his proposals to the development of that policy, which he shall carry out as mandated by the Council. The same shall apply to the common security and defence policy.

In the Lisbon-version, the Member States retained their right of initiative. Proposals to limit this right of Member States - for instance by allowing proposals from there or more Member States or to allow the European Parliament to submit proposals - were unacceptable to a number of Member States.

A proposal by the Presidium of the Convention to allow for joint proposals by the Commission and the High Representative was not accepted, because this would mean that the High Representative would need approval from the Commission for his/her proposal. ${ }^{12} \mathrm{~A}$ number of Member States were against any role of the Commission in this area. ${ }^{13}$ The result is that an active initiating role of the Commission if now formally excluded. Thus, in the current provision, and in line with the text of the Constitutional Treaty, the individual right of

\footnotetext{
12 Draft sections of Part Three with comments, CONV 727/03 (28.05.2003), p. 51.

13 Amendments No. 2 (de Villepin) and No. 6 (Hain), Summary sheet of proposals for amendments concerning external action, including defence policy: Draft Articles for Part One, Title V (Articles 29, 30 and X), Part Two, Title B (Articles 1 to 36) and Chapter X (Article X) of the Constitution, CONV 707/03 (09.05.2003), p. 56.
} 
initiative of the Commission disappeared. However, the possibility of a mandate from the Commission to the High Representative to submit a proposal may not be excluded. ${ }^{14}$

The position of the High Representative was clearly updated by the Lisbon Treaty. ${ }^{15}$ The modification from 'High Representative' to 'High Representative of the Union' further underlined his role as Union actor, rather than as representative of the Member States.

Following the text of the Constitutional Treaty, the Lisbon Treaty added the High Representative to the actors with a right to submit proposals. The High Representative may use this initiative individually or "with the Commission's support". Given the position of the High Representative in the Commission and the clear links between the different aspects of EU external relations, it is difficult to see how he could initiate new CFSP in the absence of support by the Commission. On the other hand, the position of the High Representative is independent. Within the broad area of EU external relations different or even conflicting proposals by the Commission and the High Representative are not excluded.

Until the European External Action Service is fully operational, ${ }^{16}$ it is assumed that preparation of CFSP decisions takes place by the Council secretariat rather than by the Commission's DG Relex. In practice the difference between an autonomous High Representative initiative and one supported by the Commission will primarily have consequences for the way in which the proposal is prepared. Also, assumedly, it will have consequences for the subsequent decision-making procedure as the Commission's involvement may point to a legal basis in the TFEU.

Article 30 TEU mentions that apart from proposals 'initiatives' may be submitted to the Council. The term already appeared in the text of the Constitutional Treaty. The difference between the two is not clarified by the Treaty itself. In other areas of the Union only 'proposals' may be submitted (by the Commission; compare Arts. 293 and 294 TFEU). The reason may be that not all CFSP actions take the form of formal decisions. On the basis of Art. 25 TEU the Union shall conduct its CFSP not only by adopting decisions, but also by defining the general guidelines and by strengthening systematic cooperation between the Member States in the conduct of policy. The use of the term 'initiative' in Art. 30 TEU is striking as one could argue that an 'initiative' by, for instance, the High Representative, in most cases is not a prerequisite for the Council to adopt a decision. It may adopt decisions in the absence of a formal initiative being taken by the High Representative and it may also

\footnotetext{
${ }^{14}$ As argued by the Presidium of the convention; CONV 727/03 (27.05.2003), p. 51.

15 More extensively: Kaddous 2008, p. 206.

16 See on the EEAS see, for instance, Crowe 2008; Vanhoonacker/Reslow 2010; Duke 2009; Duke/Blockmans 2010; see also the contribution of Cherubini in this volume.
} 
deviate from a proposal submitted by a Member State. Only in a limited number of cases the Treaty seems to have foreseen a true procedural function of initiatives by the High Representative, in the sense that an initiative is needed for the Council to be able to act. On the basis of Art. 31.2 TEU the Council may act by qualified majority "on a proposal which the High Representative of the Union for Foreign Affairs and Security Policy has presented following a specific request from the European Council" and Art. 33 TEU provides that "the Council may, on a proposal from the High Representative of the Union for Foreign Affairs and Security Policy, appoint a special representative with a mandate in relation to particular policy issues."

In addition, the Treaty refers to a number of other specific institutional issues in which a proposal by the High Representative seems to have a more formal role. Thus, Art. 27.3 TEU states that "The Council shall act on a proposal from the High Representative after consulting the European Parliament and after obtaining the consent of the Commission" when deciding on the organization and functioning of the European External Action Service; Art. 42.3 TEU states that "The Council shall adopt by a qualified majority, on a proposal from the High Representative of the Union for Foreign Affairs and Security Policy" decisions related to the start-up fund for expenditure arising from operations having military or defence implications; Art. 218.3 TFEU states that "the Commission, or the High Representative of the Union for Foreign Affairs and Security Policy [...] shall submit recommendations to the Council" in relation to the negotiation of international agreements; and Art. 329.2 TFEU states that "the High Representative of the Union for Foreign Affairs and Security Policy [...] shall give an opinion on whether the enhanced cooperation proposed is consistent with the Union's common foreign and security policy."

\section{The Right to Convene an Extraordinary Council Meeting}

\subsection{From Maastricht to Nice}

The possibility to convene an extraordinary Council meeting when it is not possible or not preferred to await the next regular Council meeting is closely linked to the right of initiative and has been part of the CFSP institutional machinery from the outset. The original Art. J.8.4 TEU-Maastricht listed the possibility as follows:

In cases requiring a rapid decision, the Presidency, of its own motion, or at the request of the Commission or a Member State, shall convene an extraordinary 
Council meeting within forty-eight hours or, in an emergency, within a shorter period.

The initiative was thus laid in the hands of the Presidency, albeit that the Commission and Member States could request the Presidency to convene an extra meeting. The provision returned in the TEU-Amsterdam in the same wordings (Art. 22.2) as well as in the TEU- Nice (Art. 22.2), with one minor modification ('48 hours' instead of 'forty-eight hours').

\subsection{From the Constitutional Treaty to the Treaty of Lisbon}

The Constitutional Treaty moved the competence to convene an extraordinary meeting from the Presidency to the 'Union Minister for Foreign Affairs' (Art. III-299 TCE), in line with the foreseen role of the Union Minister as president of the Foreign Affairs Council. Although there are good reasons to argue that the Presidency operates as a 'Union actor' rather than as a Member State, the importance of this shift should not be underestimated. For the first time the Council could be convened on the initiative of the EU itself.

Following the text of the Constitutional Treaty, Art. 30.2 TEU moved the competence to convene an extraordinary Council meeting from the Presidency to the High Representative. Article 30.2 TEU now states:

In cases requiring a rapid decision, the High Representative, of his own motion, or at the request of a Member State, shall convene an extraordinary Council meeting within 48 hours or, in an emergency, within a shorter period.

It is interesting to note that the possibility for the Commission to request an extraordinary meeting was deleted. Taken together with the removal of the individual right of initiative of the Commission under CFSP (supra) this underlines the upgraded position of the High Representative, but at the cost of the Commission. Member States still have a possibility to request the High Representative to convene an extraordinary emergency meeting.

\section{Unanimity and Constructive Abstention}

\subsection{From Maastricht to Nice}

The unanimity rule is at the heart of the 'intergovernmental' image of CFSP. Indeed, it is safe to assume that the inclusion of CFSP in the Maastricht Treaty was possible only because of 
the absence of majority voting, or more generally: the inapplicability of the 'Community method'. The original Art. J.8.2 TEU-Maastricht stated:

\section{[...] The Council shall act unanimously, except for procedural questions and in} the case referred to in Article J.3(2).

This is not to say that majority voting has not been debated. The Rome II European Council meeting in 1990 decided on the wish to include a provision which would make decisionmaking possible, despite the non-participation or abstention of some Member States. ${ }^{17}$ However, this idea did not lead to a reference to the provision on QMV in the EC Treaty, but to a Declaration (No. 27), adopted by the IGC, providing that "with regard to Council decisions requiring unanimity, Member States will, to the extent possible, avoid preventing a unanimous decision where a qualified majority exists in favour of that decision". ${ }^{18}$ Member States under the Maastricht provisions indeed seemed to have an obligation to explain why the use of a qualified majority would not be possible in a certain case, but the Declaration could never be used to overrule the provision in Art. J.8 TEU-Maastricht. Nevertheless, it is generally assumed that the possibility of QMV has never been used in practice and that unanimity was at the basis of the cooperation.

The slow progress of CFSP in the early days was partly blamed on the fact that because of the unanimity rule the entire decision-making process could be hijacked by one individual Member State. The 1997 Amsterdam Treaty therefore introduced the possibility of abstentions. Article 23.1 TEU-Amsterdam stated:

Decisions under this Title shall be taken by the Council acting unanimously. Abstentions by members present in person or represented shall not prevent the adoption of such decisions.

This was the general rule: decisions could (and can) be adopted when there are no 'No' votes. Article 23 TEU-Amsterdam also introduced a different possibility to prevent Member States from being bound by the decision:

\footnotetext{
${ }^{17}$ See European Council, Presidency Conclusions, Rome, 1990.

${ }^{18}$ A similar provision was already included in the Single European Act, Article 30, paragraph 3(c). It is striking that this provision was 'reduced' to a Declaration.
} 
When abstaining in a vote, any member of the Council may qualify its abstention by making a formal declaration under the present subparagraph. In that case, it shall not be obliged to apply the decision, but shall accept that the decision commits the Union. In a spirit of mutual solidarity, the Member State concerned shall refrain from any action likely to conflict with or impede Union action based on that decision and the other Member States shall respect its position. If the members of the Council qualifying their abstention in this way represent more than one third of the votes weighted in accordance with Article 148(2) of the Treaty establishing the European Community, the decision shall not be adopted.

At first sight this opened the possibility of so-called "coalitions of the able and willing"; CFSP actions no longer depended on the approval and implementation of all Member States, the more flexible approach allowed for smaller groups of states to engage in a certain action or to adopt a position. On closer inspection, however, non-participation through the issuing of a formal declaration did not at all deprive the abstaining Council member from obligations based on the adopted decision. After all, the decision taken by the Council remains a 'Union decision'. While the abstaining state may not be asked to actively implement this decision, it had to accept that 'the decision commits the Union'.

This is underlined by the rule that "in a spirit of mutual solidarity, the member state concerned shall refrain from any action likely to conflict with or impede Union action based on that decision". The wording of this provision closely resembles that in the general loyalty clause, which at the time could be found in Art. 11.2 TEU-Amsterdam: "[the Member States] shall refrain from any action which is contrary to the interests of the Union or likely to impair its effectiveness as a cohesive force in international relations" (the loyalty obligation can currently be found in Art. 24.3 TEU-Lisbon in a slightly different wording). Indeed, both provisions seriously limited the freedom of Member States, even in the case where a formal declaration of abstention has been issued. No national action that could possibly conflict with or impede Union action was allowed. From the outset this limited the advantage of the option of abstention to cases in which the Member State had little or no interest and indeed no plans for an individual national policy. Moreover, the declarations of dissent could even seriously undermine the effectiveness of CFSP decisions in relation to third states. This is the reason why the option of 'constructive abstention' in Art. 23 TEU-Amsterdam was sometimes referred to as 'destructive abstention'. It is acknowledged that this, indeed, took away much of the rationale of the declaration of abstention. 
Nevertheless, the possibility of constructive abstention returned in the 2001 Nice Treaty. In addition, Art. 23 TEU-Nice brought an end to all possible speculations as to whether abstentions can or cannot block a decision by stipulating that "[a]bstentions by members present in person or represented shall not prevent the adoption of such decisions". This implied that in that case a decision could be taken. However, there seemed to be no legally relevant advantage in using this opportunity, since it followed from the text of this provision that the abstaining Member State(s) would nonetheless be bound by the adopted decision.

\subsection{From the Constitutional Treaty to the Treaty of Lisbon}

The 2005 Constitutional Treaty maintained both the unanimity and the abstention rules in Art. III-300.3 TCE with minor changes in terminology only. The general rule that "Abstentions by members present in person or represented shall not prevent the adoption by the Council of acts which require unanimity" was no longer referred to in the CFSP provisions, but returned in Art. III-343.3 TCE. In turn, the Lisbon Treaty adopted the text of the Constitutional Treaty in its Art. 31.1 TEU:

Decisions under this Chapter shall be taken by the European Council and the Council acting unanimously, except where this Chapter provides otherwise. The adoption of legislative acts shall be excluded.

When abstaining in a vote, any member of the Council may qualify its abstention by making a formal declaration under the present subparagraph. In that case, it shall not be obliged to apply the decision, but shall accept that the decision commits the Union. In a spirit of mutual solidarity, the Member State concerned shall refrain from any action likely to conflict with or impede Union action based on that decision and the other Member States shall respect its position. If the members of the Council qualifying their abstention in this way represent at least one third of the Member States comprising at least one third of the population of the Union, the decision shall not be adopted. 
Thus unanimity is still the rule, which stands in stark contrast to the other EU policies where QMV has been established as the default voting rule. German and French proposals to make QMV the default option did not make it. ${ }^{19}$

A novel element in this provision is the explicit exclusion of the adoption of 'legislative acts'. If anything, this element clearly distinguishes CFSP from the other Union policy areas. The Constitutional Treaty already excluded "European laws and framework laws" from the instruments to be used for CFSP, which could only be shaped on the basis of "European decisions" (Art. I-40.6 TCE). The exclusion of 'legislative acts' in Art. 31.1 TEU is confirmed by Art. 24.1 TEU:

[...]The common foreign and security policy is subject to specific rules and procedures. It shall be defined and implemented by the European Council and the Council acting unanimously, except where the Treaties provide otherwise. The adoption of legislative acts shall be excluded.[...]

The CFSP instrument is therefore the 'Decision' (compare Art. 25.1 TEU), which should not be confused with the 'Decision' used in other policy areas. This latter type of 'Decision' is still one of the key legal acts of the Union and is described in Art. 288 TFEU ("A decision shall be binding in its entirety. A decision which specifies those to whom it is addressed shall be binding only on them."). The exclusion of the adoption of legislative acts does not deprive the CFSP Decisions of their legal nature. Their binding nature is confirmed by Art. 28.2 TEU ("Decisions referred to in paragraph 1 shall commit the Member States in the positions they adopt and in the conduct of their activity.") In fact, the exclusion of legislative acts primarily has to do with the exclusion of the legislative procedure and hence with the inapplicability of the role of the Commission and the European Parliament in this procedure.

As in the pre-Lisbon TEU, abstentions do not prevent the adoption of decisions, unless the number of Member States qualifying their abstention by issuing a formal declaration represent at least one third of the Member States comprising at least one third of the population of the Union. The phrasing of these criteria deviates somewhat from the preLisbon text, which referred to more than one third of the votes weighted according to the QMV rules. The new rule can be explained on the basis of the changed QMV rules, although there does not seem to be an exception for the period until 2014. The general rationale of this

\footnotetext{
19 Amendments No. 6 (de Villepin) and No. 10 (Fischer), CONV 707/03 (09.05.2003), p. 60.
} 
rule is clear: it is difficult to maintain a CFSP Decision once it is not supported by the vast majority of the Member States (including the larger ones).

Article 31.1 TEU does, however, introduce a novelty in relation to the actors involved in decision-making. The explicit competence of the European Council to adopt CFSP decisions is new, although the pre-Lisbon TEU already allowed for the European Council to adopt 'Common Strategies'. The new competences in Art. 31 TEU should be seen in the context of Art. 22 TEU, which allows for the European Council to "identify the strategic interests and objectives of the Union.” That article furthermore provides that:

Decisions of the European Council on the strategic interests and objectives of the Union shall relate to the common foreign and security policy and to other areas of the external action of the Union. Such decisions may concern the relations of the Union with a specific country or region or may be thematic in approach. They shall define their duration, and the means to be made available by the Union and the Member States.

In addition Art. 26.1 TEU provides:

The European Council shall identify the Union's strategic interests, determine the objectives of and define general guidelines for the common foreign and security policy, including for matters with defence implications. It shall adopt the necessary decisions.

The last sentence in the Article seems to imply that the 'general guidelines' are not to be seen as 'decisions'. The practical relevance of that distinction is not clear, apart from the obvious fact that guidelines may not be adopted on the basis of QMV (see below). They do seem to be binding on the Member States as the loyalty obligation in Art. 24.3 TEU is not limited to 'Decisions'. On the other hand, they do not seem to be able to function as a source of QMV in the Council, as Art. 31.2 TEU only refers to 'a decision of the European Council'.

\section{Towards Qualified Majority Voting in CFSP?}

\subsection{From Maastricht to Nice}

The debate on majority voting has been present in CFSP negotiations from the outset. An early compromise was found in Declaration No. 27, adopted by the Maastricht IGC, providing 
that "with regard to Council decisions requiring unanimity, Member States will, to the extent possible, avoid preventing a unanimous decision where a qualified majority exists in favour of that decision" (see supra). At the same time QMV was never completely ruled out. An explicit possibility was already included in the 1992 Maastricht Treaty. "The case referred to in Article J.3(2)" was mentioned in Art. J.8 TEU-Maastricht as one of the exceptions to the general rule that "the Council shall act unanimously". Article J.3.2 TEU-Maastricht indeed ordered the Council to define the matters on which decisions were to be taken by qualified majority when it adopted a Joint Action and during the further development of the Joint Action. Nevertheless, the decision to adopt a Joint Action remained subject to the rule of unanimity. When the Council would make use of this possibility, the votes of its members would have to be weighted in accordance with the Community procedures on QMV. However, the rare attempts to introduce majority voting in particular decision-making procedures were supposedly blocked by the British, which made others reluctant to make further proposals to that end. ${ }^{20}$

An important step was taken in the 1997 Amsterdam Treaty. Whereas the 1992 Treaty limited QMV to the implementation of Joint Actions (and only after a unanimous decision to that end had been taken), the new Art. 23.2 TEU-Amsterdam called for QMV by the Council when it adopts Joint Actions, Common Positions or other Decisions on the basis of a European Council Common Strategy, or when it adopts a decision implementing a previously adopted Joint Action or Common Position. Art. 23.2 TEU-Amsterdam thus read:

By derogation from the provisions of paragraph 1, the Council shall act by qualified majority:

- when adopting joint actions, common positions or taking any other decision on the basis of a common strategy;

- when adopting any decision implementing a joint action or a common position.

In addition, a Council member could still declare that, for important and stated reasons of national policy, it intended to oppose the adoption of a decision to be taken by qualified majority, in which case a vote would not be taken (Art. 23.2, part 2 TEU-Amsterdam). Since 'important' was not defined by the Treaty, this provision provided opportunities for Member States to block Council decision-making. A way out of this was offered by the provision that in that event, the Council may, acting by a qualified majority, request that the matter be

\footnotetext{
${ }^{20}$ Keukeleire 1998, p. 291.
} 
referred to the European Council for decision by unanimity. While the Heads of State and Government may indeed be able to settle the issue in connection with other agenda items, it is obvious that this provision put the possibility of QMV into perspective.

The Amsterdam TEU provided that the votes of the members of the Council shall be weighted in accordance with the Community rules and that "[f]or their adoption, decisions shall require at least 62 votes in favour, cast by at least 10 members." At the same time, it made clear that QMV could never be used for the adoption of "decisions having military or defence implications" (par. 2; see further below).

Irrespective of the fact that the Council continued to strive for consensus, the 2001 Nice Treaty maintained the possibility of QMV. In Art. 23.2 TEU-Nice it even added a third possibility to the two introduced by the Amsterdam TEU. Apart from decisions based on a European Council Common Strategy and implementing decisions, QMV could also be used "when appointing a special representative in accordance with Article 18(5)."

QMV continued to be based on the Community rules, but the Nice Treaty somewhat tightened the rules with a view to ensuring that adopted CFSP decisions would enjoy sufficient support by the (larger) Member States:

For their adoption, decisions shall require at least 232 votes in favour cast by at least two thirds of the members. When a decision is to be adopted by the Council by a qualified majority, a member of the Council may request verification that the Member States constituting the qualified majority represent at least $62 \%$ of the total population of the Union. If that condition is shown not to have been met, the decision in question shall not be adopted.

A completely different opportunity for the Council to escape unanimity is when the question is 'procedural', in which case the Council shall act by a majority of its members. Article J.8.2 TEU-Maastricht already included this exception:

\section{[...] The Council shall act unanimously, except for procedural questions [...].}

Nowhere in Art. J.8 TEU-Maastricht, nor in any other part of the Treaty were these 'procedural questions' further defined or was the procedure for their adoption provided. The only possible conclusion on the basis of Art. J.8 TEU-Maastricht was that they need not be adopted unanimously. Hence, one could argue that a simple majority would be sufficient. 
However, the conclusion that the adoption of procedural questions was subject to the rules governing QMV was more in line with the context of the CFSP Title in the Maastricht TEU, in which the only other exception to the unanimity rule was dealt with by QMV as well.

The 1997 Amsterdam Treaty settled the question on what kind of majority should be used to decide on procedural questions in its Art. 23.3 TEU-Amsterdam:

For procedural questions, the Council shall act by a majority of its members.

This text returned in the 2001 Nice version in exactly the same wording (Art. 23.3 TEUNice).

Finally, one issue area still managed to escape from QMV: decisions having military or defence implications continue to be taken on the basis of unanimity. The Maastricht Treaty allowed for the possibility that the Council decide on an ad hoc basis that implementation of a particular decision could take place on the basis of QMV (see above). Ironically, this option was used for a decision which obviously had defence implications (a Joint Action on antipersonnel mines). ${ }^{21}$ Since the Treaty of Amsterdam, in which the structural possibility of QMV was introduced, the treaties have excluded "decisions having military or defence implications" from decision-making by QMV (see Art. 23.2 TEU-Amsterdam and TEU-Nice: “This paragraph shall not apply to decisions having military or defence implications").

\subsection{From the Constitutional Treaty to the Treaty of Lisbon}

At the time of the Convention for Europe which was to prepare the IGC on the 2005 Constitutional Treaty, it became clear that a 'communautarisation' of CFSP would meet strong resistance from some larger Member States (led by the United Kingdom). It became obvious that CFSP would maintain a somewhat distinct position in the Treaty, despite the fact that a preference for more QMV was expressed by Working Group VII on External Action. In its final report this Working Group argued the following in relation to decision-making in CFSP: $:^{22}$

\footnotetext{
${ }^{21}$ Council Decision 95/170/CFSP concerning the joint action adopted by the Council on the basis of Article J.3 of the Treaty on European Union on anti- personnel mines, O.J. L 115/1 (1995) Article 6, paragraph 3.

${ }^{22}$ CONV 459/02 (16.12.2002), point 8.
} 
“- The Working Group underlines that, in order to avoid CFSP inertia and encourage a proactive CFSP, maximum use should be made of existing provisions for the use of QMV, and of provisions allowing for some form of flexibility, such as constructive abstention.

- In addition, the Working Group recommends that a new provision be inserted in the Treaty, which would provide for the possibility of the European Council agreeing by unanimity to extend the use of QMV in the field of CFSP;

- Several members consider that 'joint initiatives' should be approved by QMV.”

Article III-300.1 TCE nevertheless maintained the "unanimity rule ("The European decisions referred to in this Chapter shall be adopted by the Council acting unanimously").

Article III-300.2 TCE listed four exceptions to the unanimity rule. Three situations in which QMV could be used where already part of the Amsterdam regime (albeit perhaps in a somewhat modified language):

(a) when adopting European decisions defining a Union action or position on the basis of a European decision of the European Council relating to the Union's strategic interests and objectives, as referred to in Article III-293(1);

In line with the overall use of the term 'European decisions' for all CFSP legal acts, in this provision the Common Strategies of the European Council were replaced by 'European decisions of the European Council relating to the Union's strategic interests and objectives'.

(c) when adopting a European decision implementing a European decision defining a Union action or position;

(d) when adopting a European decision concerning the appointment of a special representative in accordance with Article III-302.

One situation was new:

(b) when adopting a European decision defining a Union action or position, on a proposal which the Union Minister for Foreign Affairs has presented following a specific request to him or her from the European Council, made on its own initiative or that of the Minister; 
This could certainly be seen as a major step. The Constitutional Treaty thus allowed for the Council to adopt CFSP decisions by QMV once these decisions were based on a proposal by the Union Minister for Foreign Affairs. At the same time the compromise is clearly visible in this provision: at the level of the European Council all Member States would have the possibility to block a request to the Union Minister to submit a proposal.

In a different part of the Constitutional Treaty one comes across an additional exception to the unanimity rule. Article III-313.3 TCE regulated the setting-up and financing of a start-up fund for expenditure arising from operations having military or defence implications. Article III-311.2 TCE allows for QMV to be used in relation to the establishment of the European Defence Agency; and Art. III-312 TCE mentions QMV in relation to some decisions taken with regard to the Permanent Structured Cooperation in the Common Security and Defence Policy (see further below).

All in all, the Constitutional Treaty thus substantively extended the possibilities for QMV in the CFSP area. At the same time, however, the possibility introduced by the Amsterdam Treaty to allow Member States to block the possibility of QMV returned in Art. III-300.2 TCE:

If a member of the Council declares that, for vital and stated reasons of national policy, it intends to oppose the adoption of a European decision to be adopted by a qualified majority, a vote shall not be taken. The Union Minister for Foreign Affairs will, in close consultation with the Member State involved, search for a solution acceptable to it. If he or she does not succeed, the Council may, acting by a qualified majority, request that the matter be referred to the European Council for a European decision by unanimity.

Note that the 'important and stated reasons' where replaced by 'vital and stated reasons', by which - at least on paper - the possibility to oppose QMV was further restricted. At the same time, the Constitutional Treaty introduced the possibility of the Union Minister for Foreign Affairs to act as a broker and to try and solve the issue at the level of the Council.

The 2007 Lisbon Treaty largely followed the text of the Constitutional Treaty, albeit that the terminology has been adapted to the new 'Lisbon language' ('Decision' instead of 'European decision', 'High Representative' instead of 'Union Minister'). Article 31.2 TEU thus lists the 
possibilities for QMV in the area of CFSP, and can hence be seen as providing the exceptions to the general rule of unanimity:

- when adopting a decision defining a Union action or position on the basis of a decision of the European Council relating to the Union's strategic interests and objectives, as referred to in Article 22(1),

- when adopting a decision defining a Union action or position, on a proposal which the High Representative of the Union for Foreign Affairs and Security Policy has presented following a specific request from the European Council, made on its own initiative or that of the High Representative,

- when adopting any decision implementing a decision defining a Union action or position,

- when appointing a special representative in accordance with Article 33.

In addition the use of QMV is possible in a limited number of other cases, which are to be found in other parts of the Treaty. First of all the use of QMV for the establishment and financing of a start-up fund for military and defence operations was taken over from the Constitutional Treaty. This possibility is now mentioned in Art. 41.3 TEU:

The Council shall adopt by a qualified majority, on a proposal from the High Representative of the

Union for Foreign Affairs and Security Policy, decisions establishing:

(a) the procedures for setting up and financing the start-up fund, in particular the amounts allocated to the fund;

(b) the procedures for administering the start-up fund;

(c) the financial control procedures.

Secondly, one comes across QMV in Art. 45.2 TEU in relation to the establishment of the European Defence Agency:

The European Defence Agency shall be open to all Member States wishing to be part of it. The Council, acting by a qualified majority, shall adopt a decision defining the Agency's statute, seat and operational rules. 
And finally, some decisions in relation to the Permanent Structured Cooperation in the Common Security and Defence Policy (CSDP) may be taken by QMV. With regard to notification by Member States which wish to participate in the Permanent Structured Cooperation, Art. 46.2 TEU states:

Within three months following the notification [...] the Council shall adopt a decision establishing permanent structured cooperation and determining the list of participating Member States. The Council shall act by a qualified majority after consulting the High Representative.

Later accession to the Permanent Structured Cooperation is also decided on by QMV (Art. 46.3 TEU):

Any Member State which, at a later stage, wishes to participate in the permanent structured cooperation shall notify its intention to the Council and to the High Representative.

[...] The Council shall act by a qualified majority after consulting the High Representative. Only members of the Council representing the participating Member States shall take part in the vote.

Similarly, suspension of a Member State from the Permanent Structured Cooperation may be decided upon by the Council on the basis of QMV (Art. 46.4 TEU):

If a participating Member State no longer fulfils the criteria or is no longer able to meet the commitments [...], the Council may adopt a decision suspending the participation of the Member State concerned.

The Council shall act by a qualified majority. Only members of the Council representing the participating Member States, with the exception of the Member State in question, shall take part in the vote.

As a counter-weight to all these new exceptions to the unanimity rule, the Treaty maintained the 'emergency brake' for situations in which a member of the Council declares that, for vital (the term was already introduced by the Constitutional Treaty) and stated reasons of national policy, it intends to oppose the adoption of a decision to be taken by QMV. In that case the 
High Representative will first search for a solution, before the Council may, acting by a qualified majority, request that the matter be referred to the European Council for a decision by unanimity. In line with the text of the Constitutional Treaty, the High Representative may thus act as a broker to reach a compromise at the level of the Council. The opposing Member State is just been given a choice: either accept decision-making by QMV (which will only be realistic once the draft decision takes the objections raised by the Member State into account), or move the issue to the level of the European Council (where the Member State would have the possibility to block the decision, or to link it to other strategic issues).

With regard to the question of using QMV for procedural questions, it is interesting to note that the specific CFSP provision had disappeared in the 2005 Constitutional Treaty. A reference to procedural question could only be found in the general title on the Council of Ministers, in Art. III-344.3 TCE:

\section{The Council shall act by a simple majority regarding procedural matters and for} the adoption of its Rules of Procedure

Post-Lisbon not only this provision returns (in Art. 240.3 TFEU), but also the old Nice provision in relation to the specific CFSP voting-rules: "For procedural questions, the Council shall act by a majority of its members."

At the same time this is the only situation in CFSP where neither unanimity nor QMV is used, but where decisions are being taken by a simple majority. The fact that the adjective 'simple' is left out does not seem to cause problems of interpretation. After all, in any other case the text of the Treaty refers to qualified majority voting. A question that has been left open concerns the definition of 'procedural questions'. They are not defined in the Treaties, nor in the Council's Rules of Procedure. ${ }^{23}$ This also leaves open the question whether the decision to establish that a question is procedural should itself be treated as a procedural or a non-procedural question. In other words: the Council's decision to turn an issue into a procedural question may only be taken by a majority vote once this decision is itself considered procedural. It is doubtful whether the Treaty negotiators had this last possibility in mind. After all, acceptance of this issue being procedural would potentially open a large number of issues to be decided by a simple majority.

\footnotetext{
${ }^{23}$ Council Decision 2009/937/EU adopting the Council's Rules of Procedure, O.J. L 325/35 (2009).
} 
Perhaps the most important innovation in this regard was taken by the Constitutional Treaty in the sense that it introduced a 'dynamic' move to more QMV (sometimes referred to as a passarelle clause ${ }^{24}$ ). Article III-300.3 TCE allowed the European Council to unanimously adopt a European decision stipulating that the Council shall act by a qualified majority. This opened the way to more QMV in CFSP without formal treaty amendment. The provision was taken over by Art. 31.3 TEU:

The European Council may unanimously adopt a decision stipulating that the Council shall act by a qualified majority in cases other than those referred to in paragraph 2.

Irrespective of the fact that unanimity is still the rule in CFSP, the exceptions to the rule have increased over time. In addition to the specific exceptions that were introduced since the Treaty of Amsterdam, the Lisbon Treaty took over the more general rule from the Constitutional Treaty that the European Council may unanimously adopt a decision stipulating that the Council shall act by a qualified majority. Potentially this new QMV possibility allows for a more speedy process in the Council, once the European Council has agreed on it. However, the question remains what the actual impact will be. It may be assumed that this situation relates to more structural issues as the possibility to use QMV once a Council decision is based on a decision by the European Council is mentioned separately. This would mean that the European Council has been given the competence to extend the list of (currently) four exceptions to the unanimity rule, which would indeed resemble a true passarelle. Nevertheless, in some Member States (e.g. the United Kingdom and Germany), the government will not be able to agree to the use of this passarelle without prior approval by its parliament. $^{25}$

Finally, also in the post-Lisbon period, QMV is excluded at all times in relation to 'decisions having military or defence implications' (Art. 31.4 TEU). This provision was again taken over from the Constitutional Treaty (Art. III-300.4 TCE), which also made sure to exclude the possibility that the European Council would decide on a future possibility for QMV in this area. The original draft of the provision did not exclude this possibility and the version in the Constitutional Treaty (as well as in the TEU-Lisbon) is the result of a British amendment to the text. ${ }^{26}$

\footnotetext{
${ }^{24}$ See also the contribution by Hrbek in this volume.

${ }^{25}$ Piris 2010, p. 262.

${ }^{26}$ Amendment No. 11 (Hain), CONV 707/03 (09.05.2003).
} 
Still, the distinction between 'military' and 'defence' is not made clear. At the same time it remains striking that paragraph 4 does not simply refer to 'decisions taken in the framework of the Common Security and Defence Policy (CSDP)', but to 'decisions having military or defence implications'. This could imply that also general CFSP (non CSDP) decisions having military or defence implications require unanimous support. This is underlined by the fact that this rule is mentioned under the CFSP voting modalities, rather than merely in the CSDP Title. In practice this would imply that general CFSP (non-CSDP) decisions (for instance on humanitarian assistance) would require unanimity in all phases when they would have military or defence implications. How to decide on the nature of the decisions (and hence on the applicable voting procedure) is not regulated by the Treaty, but one may assume that in these cases Member States may fall back on the general possibility to block QMV in cases of "vital and stated reasons of national policy” (see above).

\section{Concluding Observations}

The purpose of this paper was to establish whether - and to which extend - the Lisbon Treaty could be seen as another step in the development of the CFSP with a view to two main elements: the right of initiative and the voting rules. Based on earlier research on the development of the CFSP legal order, the hypothesis was that the new Lisbon rules would show a move towards a less intergovernmental CFSP.

In historical perspective a development is indeed undeniable, but the finally emerging picture is, at best, mixed. Indeed the inclusion of CFSP, together with all other Union policies in one 'Constitutional Treaty' in 2005 seemed to make an end to the specific nature of CFSP. In addition, the Constitutional Treaty introduced the "Union Minister for Foreign Affairs" modified by the Lisbon Treaty to 'High Representative of the Union' - as the successor to the "High Representative for Common Foreign and Security Policy". Thus a new, more supranational, element into the CFSP by allowing initiatives in this area to be taken by an 'agent' of the Union, rather than just by Member States. Similarly, the competence to convene an extraordinary meeting was moved from the Presidency to the High Representative, which implied that for the first time the Council could be convened on the initiative of the EU itself.

Also with regard to the voting rules, some major steps have been taken over time. The introduction of 'constructive abstention' by the Amsterdam Treaty was maintained by later treaty modifications. Together with the fact that non-participation by a Member State through the issuing of a formal declaration did not at all deprive this abstaining Council member from obligations based on the adopted decision, the procedure in practice comes closes to QMV. 
After all, the decision taken by the Council remains a 'Union decision'. While the abstaining state may not be asked to actively implement this decision, it has to accept that 'the decision commits the Union'. In addition both the Constitutional Treaty and the Treaty of Lisbon extended the possibilities for QMV. The most important innovation in this regard may very well be the introduction of the passarelle clause, which allows the European Council to unanimously adopt a decision stipulating that the Council shall act by a qualified majority. This opened the way to more QMV in CFSP without formal treaty amendment. Finally, it is worth noting that the 'important and stated reasons' which could be invoked by Member States wishing to block QMV where replaced by 'vital and stated reasons', by which - at least on paper - the possibility to oppose QMV was further restricted.

At the same time, during the Convention for Europe which was to prepare the IGC on the 2005 Constitutional Treaty it became clear that a 'communautarisation' of CFSP would be met by strong resistance from some larger Member States. The final text of the Constitutional Treaty, which largely returned in the Treaty of Lisbon, therefore even maintained many of the specific characteristic of CFSP and even introduced a few new ones. First of all the individual competence of the Commission to submit proposals (one of the crown jewels of the 'Community method') has been deleted and replaced by a possibility to submit initiatives together with the new Union Minister for Foreign Affairs. Even a proposal by the Presidium of the Convention to allow for joint proposals by the Commission and the High Representative was not accepted, because this would mean that the High Representative would need approval from the Commission for his proposal. In addition the term 'Union Minister for Foreign Affairs' in the Constitutional Treaty was replaced with 'High Representative of the Union for Foreign Affairs and Security Policy'. This replacement was caused by the changes discussed during the Lisbon IGC with the more general purpose of removing 'state like' terms. Also, proposals to limit the right of initiative of individual Member States were unacceptable to a number of them.

Thus unanimity is still the rule, which stands in stark contrast to the other EU policies where since 'Lisbon' QMV has been established as the default voting rule. German and French proposals to make QMV the default option for CFSP did not make it. Still, as a counter-weight to the new exceptions to the unanimity rule that did make it to the final text, the Treaty maintained the 'emergency brake' for situations in which a member of the Council declares that, for vital and stated reasons of national policy, it intends to oppose the adoption of a decision to be taken by QMV. Finally, the explicit exclusion of the adoption of 
'legislative acts' reveals that, despite the binding nature of its decisions, CFSP remains the odd one out in terms of the role of the European Parliament and the Court of Justice.

Even on balance, it is difficult to assess the impact of the Lisbon Treaty on the rules on the right of initiative and voting in CFSP. The new rules have come a long way since Maastricht and a development is clearly visible. However, the Treaty introduced both a number of 'intergovernmental' elements and some innovations that may potentially change the nature of CFSP. It seems to be up to the dynamics of the process itself to use the latter to make full use of the innovations in practice.

\section{References}

Cremona, M. (2006). A Constitutional Basis for Effective External Action? An Assessment of the Provisions on EU External Action in the Constitutional Treaty. EUI Working Paper, LAW No. 2006/30

Cremona, M. (2003). The Draft Constitutional Treaty: External Relations and External Action. 40(6) CMLRev, p. 1347-1366

Crowe, B. (2008). The Chatham House Report, The European External Action Service: Roadmap for Success. Available online at http://www.chathamhouse.org.uk/files/11583_0508eas_report.pdf

Denza, E. (2002). The Intergovernmental Pillars of the European Union, Oxford: Oxford University Press

Duke, S. (2009). Providing for European-level Diplomacy after Lisbon: The Case of the European External Action Service. The Hague Journal of Diplomacy, pp. 211-233

Duke, S./ Blockmans, S. (2010). The Lisbon Treaty stipulations on Development Cooperation and the Council Decision of 25 March 2010 (Draft) establishing the organisation and functioning of the European External Action Service. CLEER Legal Brief, 4 May 2010 (available at www.cleer.eu)

Gosalbo Bono, R. (2006). Some Reflections on the CFSP Legal Order. 43(2) CMLRev, pp. 337-394

Hillion, C./ Wessel, R.A. (2009). Competence distribution in EU external relations after Ecowas. Clarification or continued fuzziness? 46(2) CMLRev, pp. 551-586

Kaddous, C. (2008). Role and Position of the High Representative of the Union for Foreign Affairs and Security Policy under the Lisbon Treaty. In S. Griller and J. Ziller (Eds.). The Lisbon Treaty: Constitutionalism without a Constitutional Treaty? (pp. 205-221). Vienna: Springer 
Keukeleire, S. (1998). Het buitenlands beleid van de Europese Unie, Deventer: Kluwer

van Ooik, R.H. (2008). Cross-Pillar Litigation Before the ECJ: Demarcation of Community and Union Competences. European Constitutional Law Review, No. 4, pp. 399-419

Piris, J.-C. (2010). The Lisbon Treaty: A Legal and Political Analysis. Cambridge: Cambridge University Press

Smith, M.E. (2004). Europe's Foreign and Security Policy: The Institutionalization of Cooperation, Cambridge University Press

Wessel, R.A. (2009). The Dynamics of the European Union Legal Order: An Increasingly Coherent Framework of Action and Interpretation. European Constitutional Law Review No. 1, pp. 117-142

Wessel, R.A. (2007). The EU's Foreign, Security and Defense Policy Fifteen Years after Maastricht: A Constitutional Momentum? In H.-G. Ehrhart, S. Jaberg, B. Rinke and J. Waldmann (eds.). Die Europäische Union im 21. Jahrhundert. Theorie und Praxis europäischer Außen-, Sicherheits- und Friedenspolitik (pp. 302-316). Wiesbaden: VS Verlag für Sozialwissenschaften

Spence, D. (2006). The Commission and the Common Foreign and Security Policy. In D. Spence (ed.), The European Commission, 3rd edn. London: John Harper Publishing Stetter, S. (2007). EU Foreign and Interior Policies: Cross-Pillar Politics and the Social Construction of Sovereignty. London: Taylor \& Francis

Vanhoonacker, S./ Reslow, N. (2010). The European External Action Service: Living Forwards by Understanding Backwards. EFA Rev., pp. 1-18 